\title{
Adopting Communicative Teaching Method in Computer Major Bilingual Teaching
}

\author{
Shuang Liu \\ College of Computer Science \& Engineering, Dalian Nationalities University, Dalian, China \\ Email: 1s_liaoning@163.com \\ Xizuo Li \\ College of Computer Science \& Engineering, Dalian Nationalities University, Dalian, China \\ Email: xzli@dlnu.edu.cn \\ Li Zuo \\ College of Economics and Management, Dalian Nationalities University, Dalian, China \\ Email: zuoli@dlnu.edu.cn
}

\begin{abstract}
Due to less interaction between teacher and students and too much focus on professional terms in computer major bilingual teaching, some key approaches of communicative teaching method (CTM) are introduced into computer major bilingual teaching. Based on the summarization of practice experiences in English teaching training abroad and analysis of characteristics of CTM, an improved teaching method is proposed in computer major bilingual teaching such as software engineering. Using this new method, students' capability of expressing professional knowledge in listening and speaking with English will be improved.
\end{abstract}

Index Terms - communicative teaching method, eliciting, teaching plan, group work, computer major

\section{INTRODUCTION}

The authors attended a bilingual training program in New Zealand organized by Dalian Nationalities University from July to August this year. The training organizer, Edenz Colleges (Edenz Colleges, 2010), seated at the center of Auckland, adopted a teaching method called communicative teaching method, which is totally different from our traditional English teaching aiming at examination. Using this teaching method, teacher focuses on communicating with students, trying their best to elicit students to learn new knowledge, not giving presentation directly. Teacher will know every student quickly and give each one at least one chance to answer questions in class. Students participate in the class actively. When introducing games into warm up or lead in stage, students feel very interested in the class. Free speaking is necessary in each lesson. Guided by teacher, students will express themselves freely in English.

Although bilingual teaching in computer major is different from English teaching using CTM, we can adopt some excellent features of CTM in some extent.

The paper is organized as follows. Section II introduces how to practice CTM in English teaching. Section III summarizes characteristics of CTM. Section IV analyses current status of computer major bilingual teaching. Section V proposes a new teaching method, integrating CTM into computer major bilingual teaching. And Section VI gives conclusions.

\section{Teaching Practice Using Communicative Teaching Method}

When training in Edenz colleges, teachers gave us grammar, vocabulary, listening, reading, writing and grammar lessons systematically and thoroughly. We not only knew CTM in English teaching, but also adopted this new teaching method from teaching content to form. Except that, to ensure finish each teaching practice successfully using CTM, we have to prepare each lesson carefully and designed each lesson intensively. Here, one listening lesson practiced by the author is given as an example to show how to adopt CTM in English teaching.

Before class, teacher needs to prepare a teaching plan, vocabulary cards including stress, syllables and part of speech, listening tape, topic pictures, gap-fill text and white board design. Topic of this lesson is job difference between men and women, which is illustrated in three pictures consisting of a female bank manager, a male nursery school teacher and a female engineer. Key vocabulary such as ambitious, persuade, qualification, challenge, satisfaction, stressful, promotion and academic needs to be elicited. Teacher guided students to guess right word and focus on stress, syllables and part of speech. Then concept question for each word is used to check whether students have understood the meaning. Listening tape called "working in something different" is selected corresponding to students' level. Some key words are left for students to fill when listening for detail. Discussion topic is related to listening content, that is, men and women are equally capable of doing any job. The teaching plan for this listening lesson is showed in Table I in chronological order. 
TABLE I

\begin{tabular}{|c|c|c|c|c|}
\hline \multicolumn{5}{|c|}{ LISTENING TEACHING PLAN USING CTM } \\
\hline Time & Stages & Teacher's activity & Students' activity & Purpose \\
\hline $4 \mathrm{~min}$ & Lead-in & $\begin{array}{l}\text { Tell students the listening lesson is } \\
\text { about jobs. Ask them to tell the class } \\
\text { about the jobs showing in the picture } \\
\text { and show their opinions about what } \\
\text { jobs suitable for men or women }\end{array}$ & $\begin{array}{l}\text { Students volunteer ideas from } \\
\text { their own experiences }\end{array}$ & $\begin{array}{l}\text { Get students thinking } \\
\text { about topic-working in } \\
\text { something different }\end{array}$ \\
\hline $6 \mathrm{~min}$ & $\begin{array}{l}\text { Pre-teach } \\
\text { vocabulary }\end{array}$ & $\begin{array}{l}\text { Elicit key vocabulary } \\
\text { Model, drill and write up the } \\
\text { vocabulary, eliciting stress, syllables } \\
\text { and part of speech }\end{array}$ & $\begin{array}{l}\text { Students search for the right } \\
\text { word, listen, practice } \\
\text { pronunciation and identifying } \\
\text { the stress, syllables and P.O.S }\end{array}$ & $\begin{array}{l}\text { To clarify difficult } \\
\text { vocabulary necessary } \\
\text { to complete the task } \\
\text { Establishing correct } \\
\text { pronunciation }\end{array}$ \\
\hline $5 \mathrm{~min}$ & Prediction & $\begin{array}{l}\text { Instruct students to work in pairs to } \\
\text { guess why the jobs they are working } \\
\text { are different }\end{array}$ & $\begin{array}{l}\text { Students work in pairs, listing } \\
\text { differences in their jobs }\end{array}$ & $\begin{array}{l}\text { To anticipate text } \\
\text { content }\end{array}$ \\
\hline $5 \mathrm{~min}$ & $\begin{array}{l}\text { Listening } \\
\text { for gist }\end{array}$ & $\begin{array}{l}\text { Set the task. Remind students they } \\
\text { don't have to understand everything. } \\
\text { They just need to get main idea. } \\
\text { Play the tape and get students to } \\
\text { compare their answers in pairs and } \\
\text { conduct feedback. }\end{array}$ & $\begin{array}{l}\text { Students understand the task, } \\
\text { listen to the tape and compare } \\
\text { answers with their partners. } \\
\text { Then they share answers with } \\
\text { the whole class }\end{array}$ & $\begin{array}{l}\text { To develop skills of } \\
\text { listening for gist }\end{array}$ \\
\hline $10 \mathrm{~min}$ & $\begin{array}{l}\text { Listening } \\
\text { for detail }\end{array}$ & $\begin{array}{l}\text { Set the task clearly. Play the tape. } \\
\text { Get students to compare their } \\
\text { answers in pairs. Listen carefully to } \\
\text { decide whether students need to hear } \\
\text { the tape again. Conduct feedback }\end{array}$ & $\begin{array}{l}\text { Students understand the task, } \\
\text { listen to the tape, fill in gaps } \\
\text { and compare answers with } \\
\text { their partners. Then they } \\
\text { report back to the class }\end{array}$ & $\begin{array}{l}\text { To develop skill of } \\
\text { listening for detail }\end{array}$ \\
\hline $15 \mathrm{~min}$ & Speaking & $\begin{array}{l}\text { Put students in groups of } 2 . \text { Set the } \\
\text { task. Feedback. } \\
\text { Get the group to argue with the } \\
\text { statement "men and women are } \\
\text { equally capable of doing any job" } \\
\text { and share their opinions }\end{array}$ & $\begin{array}{l}\text { Students present their } \\
\text { opinions from their } \\
\text { experiences. Others listen and } \\
\text { ask questions. } \\
\text { Each group with opposite } \\
\text { opinions chooses one to argue } \\
\text { with others }\end{array}$ & $\begin{array}{l}\text { To improve their } \\
\text { fluency with this } \\
\text { further practice. To } \\
\text { share ideas for interest }\end{array}$ \\
\hline
\end{tabular}

In class, teacher needs to complete each step in teaching plan and ensure all students participate in lesson process. More emphasis is put on expression, not errors or mistakes. In each review step, students are encouraged to present what they have finished in English to practice their speaking skill. After class, training teacher will give feedback for practice teacher on good points and shortages to improve in the future. Using CTM, full preparation is very important before class. But, teacher will feel very easy in class because his or her work is to elicit knowledge points and set task for students.

\section{ChARACTERISTICS OF CTM}

Compared with our computer major bilingual teaching (Fenhua, 2010; Zhaoyi, 2009; Jian, 2010), CTM has the following characteristics:

(1) Eliciting. We used to present everything to students, not thinking of their understanding or accepting ability. Practice shows it doesn't work for bilingual teaching. In bilingual teaching, not only professional knowledge but also language teaching are also important. Many reference papers concern about using eliciting in computer major teaching. But in our opinion, it is much harder to put it into practice because our students are used to drive in teacher's idea. On the other hand, eliciting is very popular in language teaching abroad. Teacher's task is to elicit new points from students' current knowledge with different forms and approaches. Students should try their best to find the right answer guided by the teacher. Leading, not presenting, is a teacher's job when adopting CTM. What a teacher needs to do is to know his or her students very well and try to elicit each presentation point from students. Students will feel it is easy to learn some new knowledge from their previous knowledge.

(2) Student-centered. When teaching computer major, we used to teacher-centered mode. Presentation time proportion in one lesson is about $60 \%$ to $70 \%$. Only some $10 \%$ time before class is over, students will do some exercises in reviewing knowledge points. But when teaching English using CTM, student-centered is emphasized and attach much importance. As shown in Table I, presentation by teacher is only about 15 minutes in 45 minutes lesson time. In the rest of lesson time, students do exercises, discuss related to topic and express themselves freely in English. This teaching method guided by teacher and started from students' point, helps to improve student's positivity and creativity. Differently from our traditional teaching method mostly presented by teacher, students have more chances to practice their listening and speaking skills to learn more about the language.

(3) Maximizing students talking time. Emphasis of language teaching is capability of expressing students' ideas in listening and speaking, so maximizing students talking time is one key feature of CTM. As shown in Table I, percentage of students' talking time in 45 minutes teaching time is at least 50\%. Teacher will try his or her best to encourage students to express themselves and build their confidence in expression in English. 
(4) Group work. In computer major teaching, students are required to complete their jobs individually. They seldom complete one task in one group. But when training abroad, teacher put much emphasis on group work. Even for a simple task, teacher will instruct students to check answer with one of their partners. For a complex task, students need to check answer within one group. In stages of warm up or lead in, which adopt game or competition, students must complete their jobs as one group.

(5) Minimizing teaching talking time. Purpose of language teaching is to improve students' expression ability. In lesson teaching, proportion for students' talking is enlarged while teacher's presentation is reduced. Teacher's task is to set teaching task and elicit everything from students.

(6) Various teaching methods. In computer major teaching, teachers spend most of their lesson time teaching theory content with one single teaching approach. Students will feel boring when accepting too much theory in one lesson. But teaching approaches are various using CTM, which will arouse students' interests and attention. Like memory competition, students in one group try their best to memorize as many words as they can in one minute and check word count to decide which group is the winner. Guessing word, group who guesses more words is the winner. Playing beautiful songs, students can enjoy beautiful music before introducing class topic. Each warm up or lead in for every lesson is different and is of interest to students.

\section{CurRent Status of COMPuTER Major Bilingual TeACHING}

In China, most universities set up computer major bilingual courses (Yunpeng, 2010; Tingting, 2010; Weiguo, 2010), which put too much attention on professional terms and writing ability and less attention on expression capability using English. But for most international software companies, expressing oneself fluently in English is much more important than large vocabulary and writing skill. Chinese students used to think every detail of the sentence before they speak. They are afraid to make mistakes or errors when expressing themselves. But as bilingual learning, fluency is more important than accuracy. Even if a student expresses himself with some grammar errors or pronunciation error, it doesn't matter. In other words, communication capability including speaking and listening is essential for working in multinational companies, while writing or vocabulary doesn't matter. In China, students have little chance to practice their English speaking or listening skill. What they can do is to get good marks for various kinds of exams. Now most colleges adopted infiltrative bilingual teaching methods in computer major teaching, which will help students to improve their reading skill and enlarge their vocabulary. But for training international IT software engineers, it is a long distance to go.

\section{AdOPTING CTM In COMPUTER MAJOR BILINGUAL TEACHING}

Computer major bilingual teaching is different from language teaching, so we can't adopt CTM in it totally. But we can adopt some excellent features of CTM. Based on the author's experiences in English teaching using CTM and computer major bilingual teaching, a new fusion method is put forward as follows:

(1) Integrating boring professional knowledge into games. Teacher teaches the same theory again and again, with no interests to students. But if students participate in lesson teaching process, they will be interested in what are studying. For example, in software engineering teaching (Pressman, 2005), life cycle of software development is divided into different parts, and students are instructed to rearrange these parts into one complete flow chart. Using this way, it will be much easier for students to accept new theory than presentation directly.

(2) Adding class discussion in each class. Some appropriate proportion of lesson time is left for students to discuss relevant to knowledge points. To ensure all students participate in discussion using target language, feedback is necessary after each discussion to check whether they exchange ideas within one group and get common view for the topic. When doing requirements analysis in software engineering, students work in different groups finish requirements analysis deliverables and present in the class.

(3) Broadening interaction between students and teacher. For professional terms teaching, teacher adopts eliciting technique, leading students to think and search for the right word. What students need to do is trying their best to learn new terms based on what they have learned. For discussion stage, teacher provides some direction or suggestions to help students. Teacher should encourage students to express themselves in English, share their ideas with partner, group and class. Students will feel boring if a teacher talks too much in a class. One rule is to minimize teacher talking time and maximize students talking time. We try to practice this rule as much as we can. Students are interested in sharing their ideas and presenting in the class.

(4) Extending group work. Group work is essential for software development. It is impossible for one engineer to complete a software development with more and more complication than before. Software engineers have to work together and share their ideas together to succeed in finishing a software development in all software life cycle. Group work is a good chance for students to practice their cooperation and communicative ability. They can discuss requirements together, write requirements together, and design system together, coding and testing together. So in bilingual teaching, students are required to complete one software requirements analysis, system design, coding and testing in one group. Deliverables are to be completed in target language using IEEE templates. In each review stages, team leader of one group needs to present what they have finished in class. 
(5) Spreading writing for important knowledge points. Besides language expression of listening and speaking skill, writing skill is also important for students' job competitive power. As mentioned in group work, students are required to complete different deliverables using normal templates. Through this training, students will improve their writing skill in regular format.

Except these approaches, other auxiliary methods such as course bilingual website support, English software and documents help and online discussion group can also be helpful for students to review what they have learned in class, study what will be taught in future and communicate with teachers or classmates with misunderstood questions or puzzling problems.

\section{CONCLUSIONS}

Teaching English in communicative teaching methods help students improve their language application capability at a large extent from listening and speaking skill to enthusiasm and initiative. Introducing CTM into computer major bilingual teaching with too much theory will not only broaden student's professional vocabulary, but also improve students' ability to express professional knowledge in English.

\section{REFERENCES}

[1] Edenz Colleges. TESOL Certificate Course. http://www.edenz.com/Page.aspx?id=28( accessed 02/11/2010).

[2] Fenhua, L. (2010). Research and practice of bilingual teaching for software engineering course. Computer Education, 4, 127$127,103$.

[3] Zhaoyi, P., Ping, W. \& Yu Z. (2009). Practical teaching research on bilingual teaching of software engineering. Computer Education, 20, 119-121, 112.

[4] Jian, W. (2010). The research and practice of bilingual teaching methods in computer English. Computer Education, 4, 80-82.

[5] Yunpeng, Zh. \& Yunting H. (2010). Curriculum reform research of introduction to computer systems. Computer Education, 9 , 83-85.

[6] Tingting, H. (2010). Special bilingual teaching model to cultivate software outsourcing talents in universities. Computer Education, 13, 67-69.

[7] Weiguo, L. (2010). Bilingual teaching practice on computer network course teaching system. Computer Education, 13, 98-100.

[8] Pressman, R. S. (2005). Software Engineering: A Practitioner's Approach, 6th edition. Boston: McGraw Hill Higher Education, 51-76.

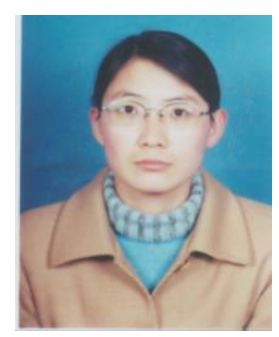

Shuang Liu, born in Jinzhou, Liaoning, China in 1977, received her PhD degree of Traffic Information Engineering \& Control from Dalian Maritime University in 2006.

She currently works as an Associate Professor at the college of computer science \& engineering, Dalian Nationalities University, Dalian, China. Her research interests include computer education, intelligent transportation system and machine learning algorithms. Her academic papers are published both national and international conferences such as High Technology Letters (2006), Lecture Notes in Computer Science 5263 (2008) and Proceedings of the Fifth International Conference on Machine Learning and Cybernetics (2006). She is also a review expert for the Journal of Systems Engineering and Electronics and the 2010 International Conference on Computer Application and System Modeling.

Dr. Liu is a member of WASE (World Association of Science Engineering) with number WASE0000257.

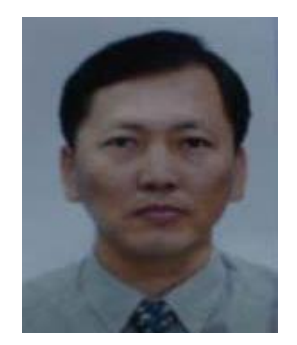

Xizuo Li was born in Jiaohe, Jilin, China in 1963. He is currently a professor and vice dean in the college of computer science \& engineering of Dalian Nationalities University. His interests include computer education, workflow models and e-learning.

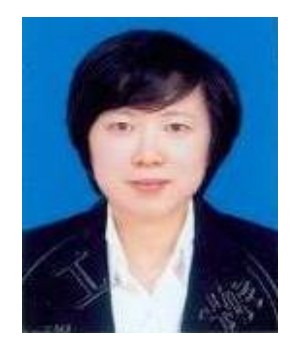

Li Zuo was born in Dalian, Liaoning, China in 1975. She received her PhD degree of Technological economic management from Dalian University of Technology in 2009. Her research interests include project management and high technology industrialization. 